the cause of Diphtheria is not an animal or regctable poison, but a state of the air that impairs the vital status of the blood, is further shown by the following considerations. Diphtheria prevails in all scasons and climates, equally in primitive or miasmatic regions, equally in well-cleaned strects, among the better classes, or in courts and alleys among tho victims of want and vice; indeed, filth, porerty. veretable and animal effluvia, do not increase its virulence or cause its disscmination. It is not self.limited, has no fixcd stages of increment and decline, may'recur several times, does not attack indiscriminately, but, as a rule, singles ont scrofulons children, or at least individuals whose constitutions are reduced and blood impoverished; and, more than all, Diplitheria is not inceulable. M. 'T'ronsscall introduced the exudation into his arm and tonsils; and M. Peter inserted it into his lips, rubbed it orer his fances and had it coughed into his cye, withont any had result. In fine, we have no evidence that Diphtheria is contagions, or in any way passes from onc individual to another. My observation teaches me that, though more than one of a family may be attacked simultaneously, or within a few days of each other, the disease is not communicated to visitor's, or to other families in the house. It might be expected that, of a number of children of like organization and halits, breathing the same air and eating at the sarne table-or, in other words, having identical susceptibilities and similar surroundings-more than one would be attacked at or about the samo time. Generally, however, cases of Jiphtheria occur here and there in distant localities; whereas, liad contagion any influence in the matter, the disease would not be thus limited, or its victims far separated. Diphtheria has undoubtedly occurred at all periods, and in all countries of the world; but from the low intensity of the causation, the dis. ease, except in epidenic seasons, has been confined to isolated cases. Aside from croup, that may owo this origin, many cases of scarlet ferer have ended fatally on the appearance of the diphtheritic exudation. With these preliminary olsservations. I will now give the details of the most interesting cases that have fallen under my notice.

['To be continued.]

\title{
STUDIES OF ABORTION.
}

By Horatio R. Stonen, M.D., of Boston.

[Communicated for the Boston Medical and surgical Journal.]

I.

IN a series of papers published in $1858-60, *$ the writer had occasion to discuss alortion in one only of its several aspects, that relating to medical jurisprudence. The general interest then evinced

- Procecdings of the American Academy of Arts and Sciences, Dec., 18.58, vol. iv., p. 109. North American Medico-Chirurgicul Review, January to November, 1850.

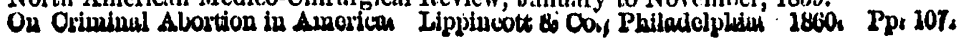


in his labors by the profession both at home and abroad, the approbation and encouragement he received, even from gentlemen who took decided issue with some of his vicws, and alove all, the practical result of the whole matter (which has prored precisely that ained at in the outset), namely, the awakening of the public conscience, the enlightenment of the pulslic mind as to the value of fotal life and the vindication of the cliaracter of the profession on this point alike in its own sight, that of the law and of the community, by the unaninous roice of the medical press, * are all convincing evidenee of the importance and lexitimacy of the inrestigation. 'l'his, howerer, though handled with all the alility I was then master of, was not cxliansted, and it may perhaps be resumed at some finture period.

In the present papers I wish to enter the field of abortion from all entirely different direction, that pertaining to obstetrics alone; and 1 think that it will be made to appear that hore also there is much of interest that has not been genorally appreciated, muny practical questions to be stripped of uncertainties and to be solied. While, therefore, I have above referred to the crininal aspects of abortion in a way I would gladly have made less personal, it is that I may the more forcibly present beforehand the inportance of the research now undertaken, and ask for it immunity from any bias that former opposition might occasion.

II $n o$ department of medicine has such immense progress been made of late jears as in obstetrics. Not merely have its theoreti. cal and more strictly scientific boundaries been widenod, but as an art, in practical crery day results, it has accomplished more in sar. ing human life than any other branch of the profession. In the treatment of all the stagres of labor at the full time this is now an acknowledged fuct, and is proved both by the results of individual practice and of mortuary statistics, as compared with former ycar's; and whether I instance the suppression of puerperal fever by recognizing its contagious character and the necessity of attending to an obvious sanitary law; the greater abstinence from ineddlesome midwilcry; the judicious use of anæsthetics in shortening labor and suppressing or preventing pucrperal conrulsions; the scparation of the piacenta in presentation of that organ; the sulstilution of turning and the long forceps for craniotomy; or the induction of premature labor when required, the acconcheur may feel a great and reasonable pride. What I have here stated as the result of closer and more thorough study of the processes of labor at the full time, I now claim may be also accomplished in the case of abortions; which, as a general rule, while alway's when completed necessarily

- In ver:fiention of this stitement, I refer to the.emrent flles of every medical journal, to the published 'Transactions of the Nitional and minor Medicil Assocditions, to many medlcal addle's:es, as thit hy Dr. Miller of Lonisville at New lInven in 1860, and to ne:mly every gener.1l olsstetif: work of nuy imp!ortance issued in this country since that diate-Bedford's

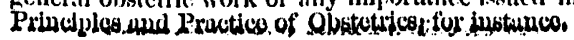


implying one death, that of the child, are also generally more fatal to the subsequent health of the mother, and I think I may even say as fatal, on the large scale, to her life, as labors at the full period.

The causes of an immediately or sccondarily fatal result of labor at the full period are few; in abortion nearly every one of these is present, with the addition of others peculiar to the sudden and untimcly interruption of a natural process and the death of the pro. duct of conception. There is the same or greater physical shock, tho same or greater liability to hamorrhage, the same and much greater liability to subsequent uterine or ovarian disease. To these clements we must add another and by no means unimportant one; a degree of mental disturbance, often profound, from disappointment or fear, that to the same extent may be said rarely to exist in labors at the full period.

Physicians as yet are hardly agreed as to the essential nature or natures of the accident, it would scem to occur from so many and varying causes, and yet it is extremely important at the very beginning of this inquiry that our ideas upon this point should be settled and correct; and then again it is of the utmost value to distinguish between proximate and predisposing causes. How different, for instance, the nature of abortions arising from mechanical violence, external or internal; from a gencral virus pervading the maternal or foetal system; from disease of the utcrine walls, or of the placental tissue, or the accidental extravasation of blood between them; and how different the treatment should be, though so generally the same.

In the diagnosis, also, of abortion there is the same latitude to be observed, and the error that may be made is one involving not merely the reputation of the attendant as a skilled obstetrician, but the life of the patient, often also her moral character. To these chances must be added also the possibilitics of preventing the completion of the morbid process, and thus of frequently saving the life of the child. In cases of secondarily transmissible diseases, as syphilis for instance, it will be seen that these inquirics receive remarkable importance as affecting the reputation and moral standing of persons who would have otherwise scemed the least liable to suspicion.

There is scarcely a phase of uterine or orarian disease that may not simulate, or be simulated by, some form of abortion, common or extreme; and there is scarcely one that may not induce or be induced by the same disturbance of gestation. How often has abortion been mistaken for dysmenorrhoea or menorrhagia, and again how many virtuous women laboring under these irregularities of function have been charged with a breach of moral discipline. In like manner has the partially detached ovum been mistaken for polypus, the expulsive contractions of the uterus for intestinal flatulence, the cachexia from retention of a dead and putrid fotus or membranes for malignant or other incurable diseasc.

Vot.. LxvirI.-No. 14 
If, as I have said, extreme importance attaches to the correct differential and causative diagnosis of abortion, this is cssentially the case also with its treatment. And here I affirm that the duty of the physician is in most cases not, as is gencrally attempted, to complete the abnormal process as soon as possible, but to arrest it; for I am satisfied, from my own experience in very many cases were there no other reason, that this can often bo done even in cases apparently desperate as far as tho foetus is concerned, and yet its life be saved. Should, however, the expulsion of the ovum be already effected or be beyond prevention, it becomes of the utmost importance that the accident should be thoroughly completed; the interesting cases bearing upon this point that have been reported in this city will be referred to hereafter, as they constitute, with those published during the present month by Dr. Matthews Duncan, of Edinburgh,* a most important contribution to our knowledge of the subject.

But the abortion completed, there is an immense field for exploration still open. The frequent or constant repetition of the occurrence in the same patient, whether from menstrual periodicity, original or acquired discase of mother or foetus, suggest questions alike of scientific and the most strictly practical interest, and it is just here that professional reputations are to bo made. I firmly believe that most if not all of these periodical cases, whatever their intrinsic nature or exciting cause, are yet to be cured and their character to become thoroughly understood. Sereral of the problems alluded to have already been explained; oxygenated salts prevent abortion when depending on certain forms of placental discase-a specific constitutional treatment, it may even be of the husband, cnables in other cases a subsequent pregnancy to progress without hindrance. These facts merely open the subject, while proving, however, what grounds we have for expecting ultimate and general success.

Before proceeding further, one erroneous supposition, arising from easily explainable misstatements, is to be met and dealt with. It has been assumed by some, and on the authority of writers of repute, that abortions from other than a criminal causo are rcally very rare. I will instance Churchill, who probably holds at present, and very descrvedly, the foremost rank as obstetrical authority in this country. Ho states, striking an average from statistics afforded by Collins, Beatty, Deubel, La Chapelle and himself, that there are over seventy-eight labors at the full time to every abortion. $\dagger$ The same result is also given, from preciscly the same data, by Dr. Clay, of Manchester, England, of recognized weight as an obstetrical writer.t

This statement I shall now proceed to refute, by the very cridenco

- On the Results of Imperfect Delivernnec. Edinlurgh Medical Jounnl, January, 1863, page 589.

+ Theory and Practice of Midwifery, 4th London Edition, p. 167.
\pm Obstetric Cyclopoudia, p. 21 . 
these gentlemen have produced for its rerification. For this purpose I have thrown their statistics into the following tabular form :-

\begin{tabular}{|c|c|c|c|}
\hline & Total Cases. & $\begin{array}{c}\text { Aloortions or } \\
\text { premnture lahors. }\end{array}$ & $\begin{array}{l}\text { Proportion } \\
\text { of do. }\end{array}$ \\
\hline 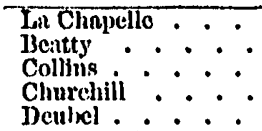 & $\begin{array}{r}21,960 \\
1,200 \\
16,414 \\
1,705 \\
420\end{array}$ & $\begin{array}{r}116 \\
21 \\
293 \\
65 \\
35\end{array}$ & $\begin{array}{l}1 \text { to } 189 \\
1 \text { to } 62 \\
1 \text { to } 66 \\
1 \text { to } 26 \\
1 \text { to } 12\end{array}$ \\
\hline
\end{tabular}

By the above it is perceived that while one observer placed the frequency of abortions as low as once to every 189 labors, another, who was probably just as unbiassed, supposed it to be once to 12 , a difference of orer seventeen fold; while Churchill himself, though broadly stating the proportion to be once to over 78 labors, in reality had found it by his own experience to be at least once to every 26 labors, or in other words precisely three times as frequent as ho would have us to believe.

Again: in striking the average from a large number of cases collected by different observers in different countries, allowance must be niade, as in all other researches of the kind, for what in astronomical language would be termed the personal equation of the observers; that is to say, for their general accuracy, their weight as authority, and the purpose, more especially, for which the observations were made. The differences between the several observers in this instance, as evidenced by their results, is so very marked as to render it impossible for us to sum these together.

Moreover, to render an average, computed from more than three elements, of probablo approximation to the truth, it is necessary that the proportion should regularly progress, positively or negatively, towards either extreme; that is, that there should be present some evident ratio or law of increase or decrease. But, on referring to the table presented, it will be found that while Madame La Chapelle, Collins, Churchill, Beatty and Deubel, as regards their total number of cases presented, stand to cach other as the numbers $1: 2: 3: 4$ : 5 , their respective rate of proportion of special cases to their sums total is as $5: 3: 2: 4: 1$. Viewed in this light the unreliability of the average becomes the more evident.

This is not all, however. The writers referred to, as indeed most others, have not taken care to eliminate those cases of advanced pregnancy which should more properly be classed as premature births, as distinguished from the carlier cases, or abortions properly so called. The importance of taking this element into consideration will be seen both from its own intrinsic value and from an. other fact pertaining to the same collection of statistics; namely, that being mostly compiled from the records of lying-in hospitals, these cases would very naturally and almost of necessity be miscarriages at an adranced period-of gestation, and therefore 'c'an' fur- 
nisl no reliable data on which to base an estimate of the comparative frequency of abortions.*

The fallaciousness of medical statistics in the settlement of questions of importance is seldom more marked than in this instance. Compiled for an entirely different purpose, their impartiality on this account cannot be appealcd to, inasmuch as they do not contain the only elcment on which an opinion can be grounded as to the frequency of the occurrence, even in hospital practice alone-to wit, the number of abortions properly so called, and distinguished from premature births; and yet the conclusion drawn from such erroneous premises has been, till now, suffered to remain unchallenged.

Lastly: the infrequency of abortions as compared with labors at the full period is disproved by the experience of every physician in special or large general practice who will faithfully investigate the subject. The truth of this statement has been fully verified in the instance of abortion criminally induced, by many of my professional friends who were at first inclined to doubt the accuracy of my inferences on that point; with reference to abortions more naturally occurring, the evidence is of course more casily arrived at and is in consequence proportionately more striking. In many cases of sterility it will be found that the number of abortions in a single patient have been almost innumerable; and, it may be added, in a large proportion of the cases of uterine discase occurring in the married, inquiry as to their past history will reveal abortions, unsuspected perhaps cven by the family physician, as the cause. It is not so much the general practitioner, the hospital attendant, or the accoucheur as such, who can testify as to the true frequency of abortion; for many cases, even of the most deplorably fatal results, do not seek for medical assistance at the time of the accident. The real balance sheet of these cases is to be made out by the hands which are more especially called to the treatment of chronic uterine disease.

Hotel Pelham, 25th January, 1863.

\section{Ahmp Arerical Entelligence.}

Hospital Notes and Memoranda. By J. Baxter Upham, M.D., Surgeon in charge of Stanley General Hospital, 18th Army Corps, Newbern, Department of North Carolina.-This hospital was established about the 20th of November last, and was originally intended as the winter quarters of the "Hainmond General Hospital," which had been in operation during the summer months at Beaufort, the seaport town of the Department of North Carolina. The great ac-

* In this comnection, I would refer to an interesting paper ly Mr. Whiteliend in the Medical Times and Gazette for the past inonth, und to a most compreheusive articlo upon "Tho Bar Sinister" in the British and Foreign Medico-Chipurofical Reviow for the present month. 